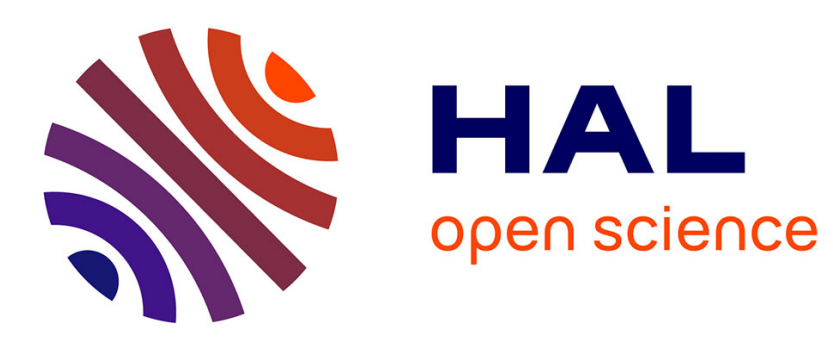

\title{
High temperature corrosion in modern thermal power generation: gas turbines, high efficiency boilers, IGCC
}

N. Bolt

\section{To cite this version:}

N. Bolt. High temperature corrosion in modern thermal power generation: gas turbines, high efficiency boilers, IGCC. Journal de Physique IV Proceedings, 1993, 03 (C9), pp.C9-741-C9-749. 10.1051/jp4:1993977 . jpa-00252419

HAL Id: jpa-00252419 https://hal.science/jpa-00252419

Submitted on 1 Jan 1993

HAL is a multi-disciplinary open access archive for the deposit and dissemination of scientific research documents, whether they are published or not. The documents may come from teaching and research institutions in France or abroad, or from public or private research centers.
L'archive ouverte pluridisciplinaire HAL, est destinée au dépôt et à la diffusion de documents scientifiques de niveau recherche, publiés ou non, émanant des établissements d'enseignement et de recherche français ou étrangers, des laboratoires publics ou privés. 


\title{
High temperature corrosion in modern thermal power generation: gas turbines, high efficiency boilers, IGCC
}

\author{
N. Bolt
}

N.V. KEMA, P.O. Box 9035, 6800 Et Arnhem, The Netherlands

\begin{abstract}
In coal fired low $\mathrm{NO}_{x}$ boilers under mild reducing conditions the use of a CrVdiffusion coating on stabilized $10 \mathrm{CrMo} 9.10$ is promising. For super heaters in oil fired super critical units, the coextruded materials with $35 \mathrm{Cr}$ and $46 \mathrm{Cr}$ are suited. For IGCC conditions coextruded 310 material is probably suitable as water wall material and $26 \mathrm{Cr} 41 \mathrm{Ni} 3 \mathrm{~V}$ as super heater material.
\end{abstract}

\section{Introduction.}

The total power capacity in the Netherlands today amounts to about $15000 \mathrm{MWe}$. From which $10000 \mathrm{MWe}$ is natural gas fired, about $4000 \mathrm{MWe}$ coal fired and about $500 \mathrm{MWe}$ nuclear based. In the last decade gas fired units have been retrofitted with gasturbines, with machine capacities ranging from 100 to $150 \mathrm{MWe}$. Experience with failure causes and repair methods was obtained in that period. In this decade twelve modern gas fired combined cycles (efficiency 55\% LHV) and cogeneration units will be constructed. Gas turbine machine capacities of 200 MWe are involved. Most of the coal fired units are special designed for or retrofitted with low $\mathrm{NO}_{x}$ burning techniques. Two super critical $600 \mathrm{MWe}$ blocks with efficiencies of $42 \%$ (LHV) are under construction. Full scale Integrated Gasification Combined Cycles are scheduled to start up from the end of this century on. A 250 MWe IGCC demonstration plant will be put in operation in 1993 at Buggenum with a efficiency of $43 \%$ (LHV).

\section{High temperature corrosion $R$ and $D$.}

In the light of the above mentioned developments, KEMA an independent organization with $R$ and $D$, testing, certification, engineering and consultancy activities in the field of the electric power supply has set up a research program on the selection of materials including background mechanisms for:

- repair of gasturbine vanes and blades;

- repair of low $\mathrm{NO}_{x}$ water wall tubes in coal fired units;

- use in super critical high efficiency boilers;

- use in first and second generation IGCC. 


\section{Gasturbines.}

In a gasturbine air is compressed, mixed with gas and burned. The flue gases enter the expander at a (nowadays) inlet temperature of $1100^{\circ} \mathrm{C}$ and enter after expansion a waste heat boiler at about $550^{\circ} \mathrm{C}$. Especially the first stage turbine blades suffer from both heat load and corrosion. The blades have got a heat pretreatment at about $850^{\circ} \mathrm{C}$. The operation temperature is in the same range resulting in structure changes during operation. Structural changes as a function of time and temperature form part of the ongoing project. Corrosion has been primarily described to the aggressive action of sodium sulphate and chloride salts. In the coastal and industrial areas the air contains sodium chloride aerosols and sulphuroxides. Especially during humid periods concentrated spots on the air filter are blown in. The molten ( $\mathrm{mp} . \mathrm{Na}_{2} \mathrm{SO}_{4} \cdot \mathrm{NaCl} 630^{\circ} \mathrm{C}$ ) salts have caused severe corrosion problems. The turbine materials consist in general of nickel or cobalt based alloys. In the nickel based alloys about $10-20 \% \mathrm{Cr}$ is present for enhanced sulphidation resistance and about $5 \% \mathrm{Al}$ for strength and oxidation resistance. In the Co-based alloys the Cr-content is higher $20-30 \%$. Because of chromium reduces the amount of the (strengthening) $\gamma$-phase its content in the super alloys is limited. Actual used materials are represented in table I.

Table I. - Actual used gasturbine materials.

\begin{tabular}{|l|l|l|l|l|l|l|l|l|l|l||}
\hline component & material & Ni & Co & Cr & W & Mo & Al & Fe & Ti & others \\
\hline $\begin{array}{l}\text { blades } \\
\text { guide }\end{array}$ & IN738 LC & bal & 8.5 & 16 & 2.6 & 1.75 & 3.4 & 0.5 & 3.4 & $1.75 \mathrm{Ta}$ \\
vanes & FSX 414 & 10.5 & bal & 29.5 & 7 & - & - & $\leq 2$ & - & $<1$ Si, Mo \\
housing & IN 617 & bal & 12.5 & 22 & - & 9 & 0.3 & 1.5 & 1.2 & $0.2 \mathrm{Cu}$ \\
\hline
\end{tabular}

Repair procedures have been developed consisting of profile reshaping, heat treatments and applying improved coatings. For instance at a damaged blade of IN $738 \mathrm{LC}$ with an original vapour sprayed coating of CoCrAlY an improved coating with an alumina diffusion layer was applied.

\section{High efficiency boilers.}

4.1 AT LOW $\mathrm{NO}_{x}$ BURNING TECHNIQUES. - the main idea is the further staging of the air supply and the separation of the flame in a fuel rich primary zone and a burning out zone where the remaining air is supplied. In general some excess air is supplied with respect to the stoichiometric burn out of the fuel. Under low $\mathrm{NO}_{x}$-firing conditions locally reducing circumstances occur near the water wall tubes, resulting in the presence of $\mathrm{CO}$ and $\mathrm{H}_{2} \mathrm{~S}$. Values of $1-5 \% \mathrm{CO}$ and up till $0.1 \% \mathrm{H}_{2} \mathrm{~S}$ have been measured in a demonstration program. From the Fe-O-S stability diagram in figure la it can be seen that already at an air/fuel-ratio of $0.9 \mathrm{FeS}$ tends to be a stable compound while chromium (Fig. 1b) forms stable oxides. At normal firing conditions (metal temperature $400-450{ }^{\circ} \mathrm{C}$, flue gas temperature about $1400{ }^{\circ} \mathrm{C}$ ) low alloyed steel types are used like 10Mo3, 13CrMo4.4, 10CrMo9.10. Candidate materials 


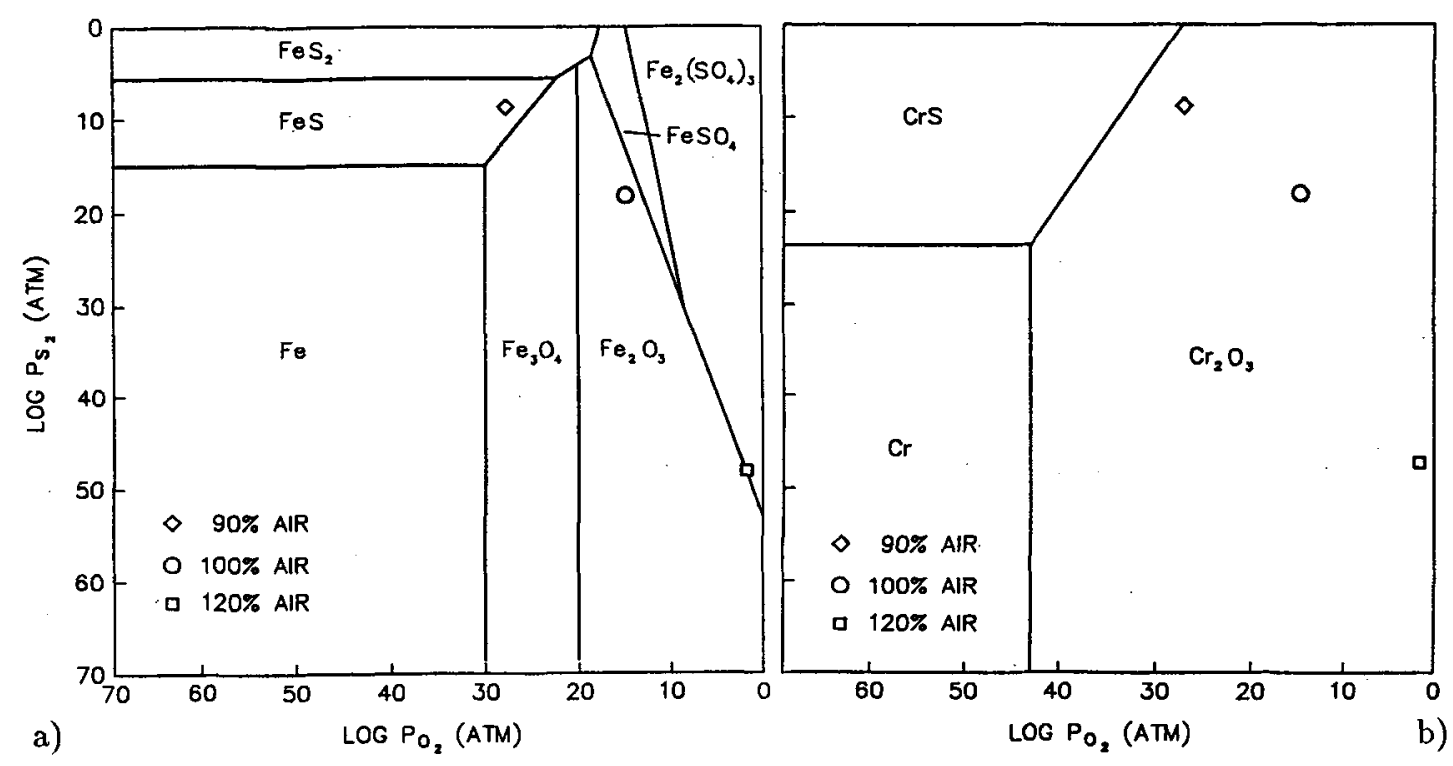

Fig. 1. - a) Stability diagram of the Fe-S-O system at $475^{\circ} \mathrm{C}$; b) Stability diagram of the Cr-S-O system at $475^{\circ} \mathrm{C}$.

with a higher sulphidation resistance have been tested. A part of some ferritic and austenitic steels, protecting layers have been examined which could easily be applied on (existing) low alloyed water wall tube sections. The project has been performed in a national program in which the government (NOVEM), universities (UT, TUE), the industry (Interturbine) and technical institutions (KEMA, TNO) were involved [1]. A selection of the materials examined is given in table $\mathbf{I I}$.

The samples have been tested on coating stability $\left(450^{\circ} \mathrm{C}\right.$ vacuum, $8000 \mathrm{~h}$ ), corrosion (general attack; $500-1500 \mathrm{~h}$ in sulphidizing gas at $450^{\circ} \mathrm{C}$, shut down attack: alternatively $80 \mathrm{~h}$ at high temperature and $50 \mathrm{~h}$ at $45^{\circ} \mathrm{C}$ in humid atmosphere) and mechanical properties (via Constant Extension Rate Techniques and Low Cycle Fatique tests). Examples of cross sections after simulation of shut down attack and CERT experiments are represented in figures 2a and $2 \mathrm{~b}$. A final judgement based on these tests has been made and is represented in table III.

It was concluded that the reference materials $15 \mathrm{Mo} 3,13 \mathrm{CrMo} 4.4$ and $10 \mathrm{CrMo} 9.10$ showed an unacceptable resistance to sulphidation and shut down corrosion. The ferritic material 446 is corrosion resistant due to the high chromium content, but the rupture/extension ratio is relatively low. Although the 310 material seems to be sensible for intercrystalline corrosion, the overall impression is positive. The $\mathrm{Cr}$ - and $\mathrm{CrV}$-diffusion coatings on $\mathrm{Nb}$ stabilized 10CrMo9.10 behave well. Because of intercrystalline shut down corrosion phenomena in the Cr-diffusion coating, the $\mathrm{CrV}$-coating seems to be the best choice. Promising materials will be tested during the period 1992-1994 in the KEMA 1 MW th coal fired plant.

4.2 HIGH EFFICIENCY BOILERS. - are a.o. characterized by their super critical steam conditions resulting in a need for stronger super heater tube materials operating at higher metal temperatures $\left(600-700^{\circ} \mathrm{C}\right.$ ). A test program for oil fired conditions has been completed, for coal fired conditions been started. To meet the demands of super critical steam pressure re- 

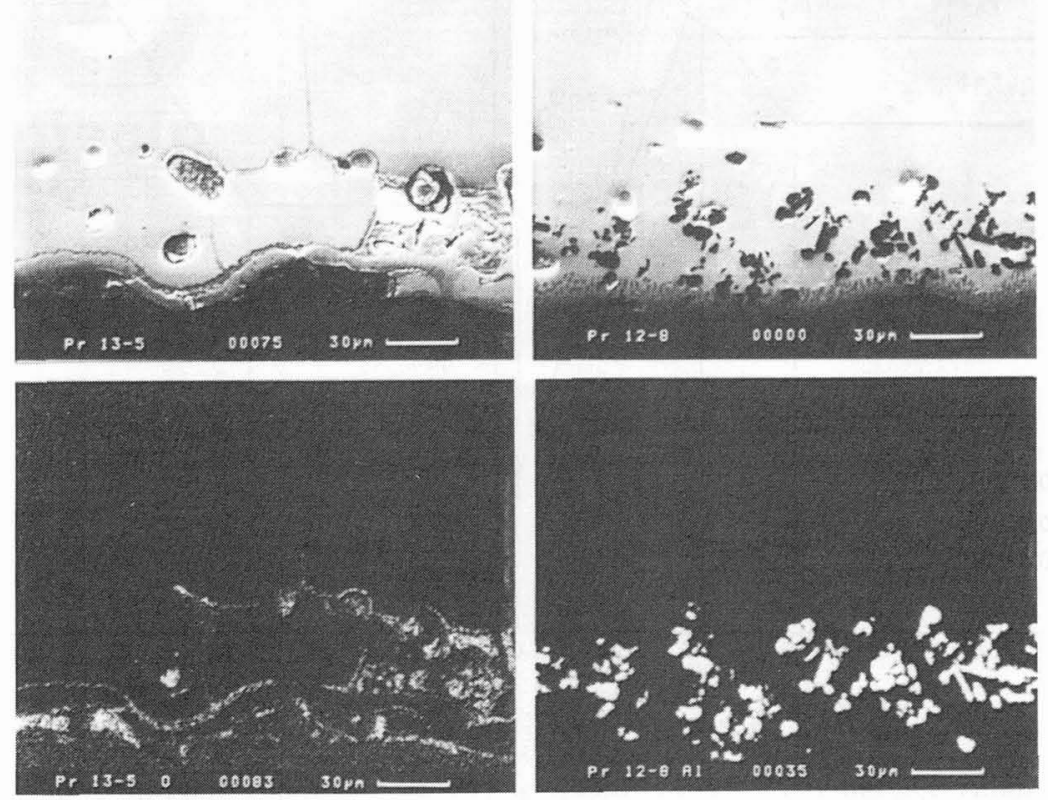

a)
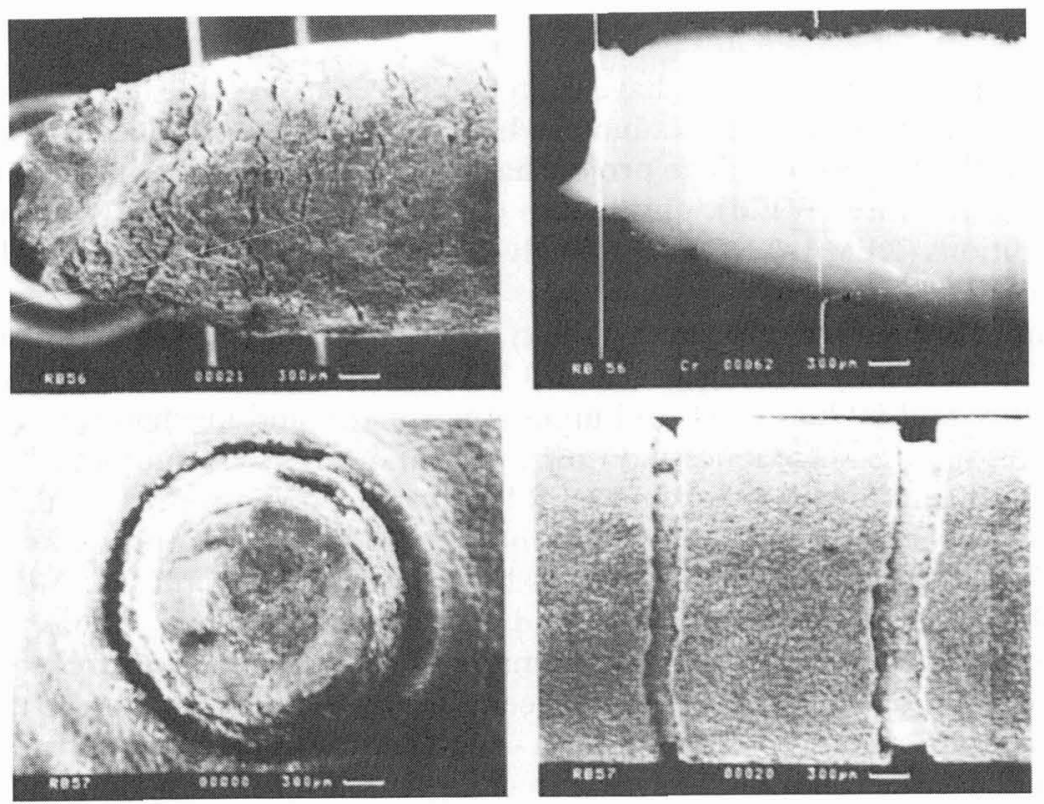

b)

Fig. 2. - a) Cr-and CrV-coatings after shut down attack simulation. The CrV-coating (12-5) is not damaged, the Cr-coating (13-5) is intercrystalline attacked; b) Coatings after CERT experiments. The CrV-diffusion coating (RB 56) shows superficial cracks, the plasma-sprayed coating (RB 57) is frequently cracked and separated from the substrate. 
Table II. - Reference and examined low $N O_{x}$ water wall materials.

\begin{tabular}{|l|l|l|l|l|l|l|l||}
\hline material & & Cr & Ni & Mo & Mn & Si & other \\
\hline 15 M03 & & - & - & 0.3 & 0.6 & 0.3 & - \\
13 CrM04.4 & & 0.9 & - & 0.5 & 0.5 & 0.2 & - \\
10 CrM09.10 & & 2.3 & - & 1.0 & 0.5 & 0.3 & - \\
Tp 446 & & 26 & 0.3 & - & 0.2 & 0.5 & $\mathrm{~N}$ \\
AIsI 310 & & 24 & 20 & - & 1.8 & 1.3 & - \\
diffusion coating & Substrate & & & & & & \\
Cr & 15M03 & 50 & & & & & \\
CrV & 10CrM09.10 & 58 & & & & & \\
\hline
\end{tabular}

Table III. — Lab tests based selection of materials for water wall tubes in low $N O_{x}$ conditions.

\begin{tabular}{|c|c|c|c|c|c|}
\hline material & $\begin{array}{l}\text { coating } \\
\text { stability }\end{array}$ & $\begin{array}{l}\text { corrosion } \\
\text { general/shut down }\end{array}$ & CERT & LCF & overall \\
\hline ip 446 & & + & - & & $+1-$ \\
\hline AISI 310 & & + & - & + & + \\
\hline Cr diff. $15 \mathrm{MO} 3$ & - & + & + & + & - \\
\hline Cr diff.10CrMo9.10 & + & - & + & + & - \\
\hline CrV diff. $15 \mathrm{Mo} 3$ & - & + & + & + & - \\
\hline CrV diff.10CrMo9.10 & + & + & + & + & + \\
\hline
\end{tabular}

sistance inside and sulphidation resistance outside, coextruded materials were selected with inside a strong and outside a high chromium-containing alloy (25-50\% $\mathrm{Cr}$ ). As a reference the conventional monobloc material AISI $347 \mathrm{H}$ was chosen. The materials (see Tab. IV) were exposed in cooled probes in the flue gases of the heavy oil fired $3 \mathrm{MW}$ th pilot plant of KEMA.

Metal temperatures are presented in figure 3a. It can be concluded that with increasing chromium content, the corrosion resistance at metal temperatures between 600 and $700{ }^{\circ} \mathrm{C}$ increases as well [2]. In the critical temperature range of $630-675^{\circ} \mathrm{C}$, where a liquid phase at the metal/deposit interface is present, the alloys Inconel 671 and NAC 35CrA behave extremely well under continuous and discontinuous load and at flue gas temperatures of 1000 and $1125^{\circ} \mathrm{C}$. In addition the ferritic steel 446 seems also to be sufficient corrosion resistant under these conditions. Analysis of the deposit build up revealed that at metal temperatures between 630 and $670^{\circ} \mathrm{G}$ a sodium-, calcium-, iron-, sulphate layer is present in the first 
$100 \mu \mathrm{m}$ from the metal/deposit interface. With DSC-DTA measurements [2] it was demonstrated that:

Table IV. - (Coextruded) materials tested in the oil fired KEMA boiler.

\begin{tabular}{|c|c|c|c|c|c|c|c|c|c|c|c|}
\hline inside/outside & manufacturer & $\mathrm{\& Cr}$ & $8 \mathrm{Ni}$ & $8 \mathrm{si}$ & $8 \mathrm{Mn}$ & \& Mo & $8 \mathrm{Nb}$ & $8 \mathrm{Cu}$ & $8 c$ & \& $P$ & 85 \\
\hline AISI $347 \mathrm{H}$ & Sandvik & 18,2 & 9.8 & 0.57 & 1,16 & - & - & - & 0,04 & 0,012 & 0.010 \\
\hline E. $1250 / 310$ & T.I. & $\begin{array}{l}15,1 \\
25,5\end{array}$ & $\begin{array}{r}9,2 \\
20,2\end{array}$ & $\begin{array}{l}0.55 \\
1,22\end{array}$ & $\begin{array}{l}5,9 \\
1,23\end{array}$ & 0,96 & 0,88 & - & $\begin{array}{l}0,12 \\
0.07\end{array}$ & $\begin{array}{l}0,025 \\
0,024\end{array}$ & $\begin{array}{l}0,014 \\
0.005\end{array}$ \\
\hline $800 \mathrm{H} / \mathrm{Tp} .446$ & Sandvik & $\begin{array}{l}20,8 \\
26,4\end{array}$ & 31,1 & $\begin{array}{l}0.43 \\
0.44\end{array}$ & $\begin{array}{l}0.56 \\
0.88\end{array}$ & - & - & 0,03 & $\begin{array}{l}0,07 \\
0,19\end{array}$ & $\begin{array}{l}0,008 \\
0,021\end{array}$ & $\begin{array}{l}0,003 \\
0,003\end{array}$ \\
\hline $1714 \mathrm{CuMO} / 35 \mathrm{CrA}$ & Nippon Kokan & $\begin{array}{l}15,3 \\
35,1\end{array}$ & $\begin{array}{l}14,5 \\
45,5\end{array}$ & $\begin{array}{l}0.54 \\
0.03\end{array}$ & $\begin{array}{l}0,75 \\
0.02\end{array}$ & 2,42 & 0,40 & $\begin{array}{l}2,96 \\
-\end{array}$ & $\begin{array}{l}0,12 \\
0,05\end{array}$ & $\begin{array}{l}0,021 \\
0,002\end{array}$ & $\begin{array}{l}0,001 \\
0,001\end{array}$ \\
\hline $800 \mathrm{H} / 671$ & Inco & $\begin{array}{l}20,0 \\
47,3\end{array}$ & $\begin{array}{l}31,2 \\
52,7\end{array}$ & 0.42 & 0.92 & $=$ & $=$ & 0,04 & $\begin{array}{l}0,11 \\
0,05\end{array}$ & - & 0,002 \\
\hline
\end{tabular}

- $\mathrm{Fe}_{2}\left(\mathrm{SO}_{4}\right)_{3} / \mathrm{Na}_{2} \mathrm{SO}_{4} / \mathrm{CaSO}_{4}$ mixtures are liquid from about $630{ }^{\circ} \mathrm{C}$;

- $\mathrm{Fe}_{2}\left(\mathrm{SO}_{4}\right)_{3}$ decomposes in $\mathrm{Fe}_{2} \mathrm{O}_{3}$ and $\mathrm{SO}_{3}$ with a maximum rate at $675^{\circ} \mathrm{C}$ at which temperature the remainder $\mathrm{Na}_{2} \mathrm{SO}_{4} / \mathrm{CaSO}_{4}$ recrystallize.

For this critical temperature range, where the maximum corrosion occurs the inward sulphur and oxygen transport reactions and the outward iron-, nickel- and chromium transport reactions are presented in figure $3 \mathrm{~b}$. It has been assumed that the supply of oxygen and sulphur $\left(\mathrm{as}_{\mathrm{SO}_{3}}\right.$ ) to the interface oxide-melt is the rate determining transport reaction. The transport of $\mathrm{SO}_{3}$ through the molten sulphate layer is diffusion-controlled and occurs according to Ficks's first law:

$$
\begin{array}{ll}
J_{\mathrm{SO}_{3}} & =-D \cdot \Delta P_{\mathrm{SO}_{3}} / X \\
D & =\text { diffusion coefficient in molten sulphate } \\
X & =\text { thickness of the molten sulphate layer } \\
\Delta P_{\mathrm{SO}_{3}} & =P_{\mathrm{SO}_{3}} \text { (melt/oxide) }-P_{\mathrm{SO}_{3}} \text { (melt/ash) }
\end{array}
$$

The flux of $\mathrm{SO}_{3}$ through the molten sulphate layer could be calculated in this way as a function of the metal temperature [2]. In figure $3 \mathrm{c}$ this relation is represented. It can be seen that both $\mathrm{SO}_{3}$-flux and corrosion rate increase rapidly with increasing metal temperatures. Above $671^{\circ} \mathrm{C}, X=0$ and the transport processes are governed by solid state diffusion: the corrosion rate drops then sharply.

\section{IGCC.}

Materials in the reactor and radiant/convection coolers at entrained bed gasifiers suffer from very aggressive conditions. Material tests under these conditions are performed in order to select materials both for service and repair at actual conditions and at near future conditions with higher metal temperatures. KEMA is involved in several test programs: at the SAR plant in Holten Germany. Participants are Ruhrchemie AG, Ruhrkohle AG, Deutsche Babcock, Man./GHH, Stork, EPRI and KEMA. At the test program in the PRENFLO-plant in Fürstenhausen (Germany) during 1992 (participants PRENFLO, EPRI and KEMA) and at 


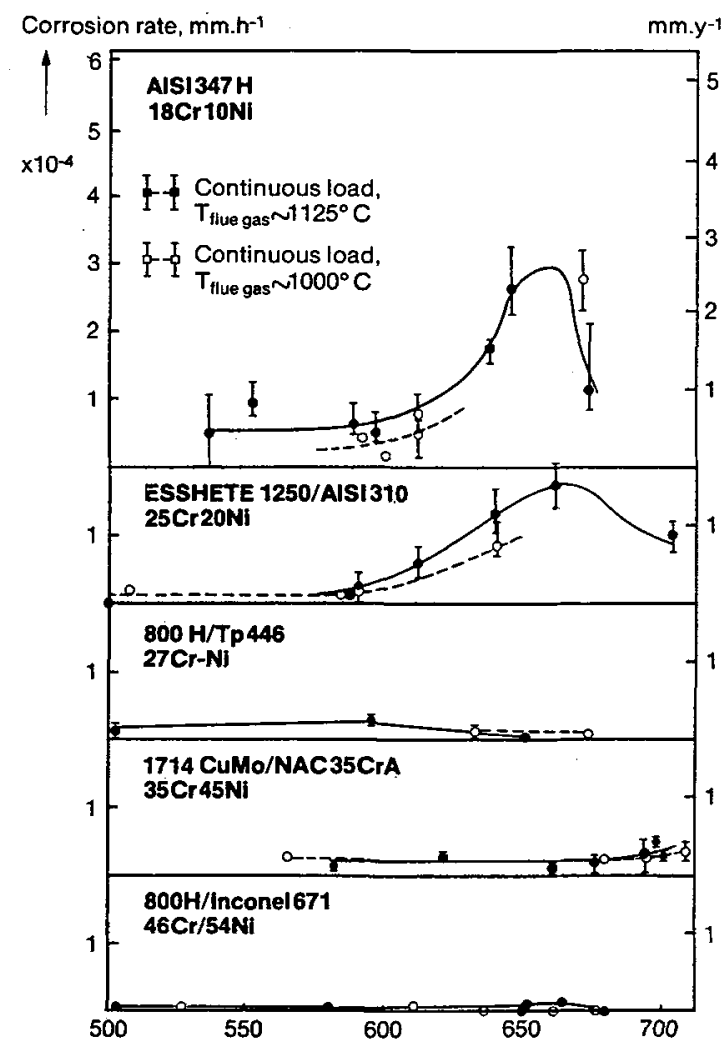

a)

$\mathrm{Fe}_{2} \mathrm{O}_{3}$ $\left(\mathrm{NiO}, \mathrm{Cr}_{2} \mathrm{O}_{3}\right.$ )

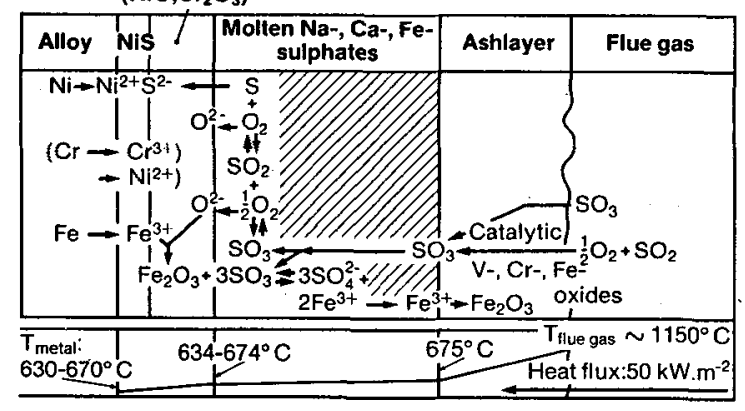

b)

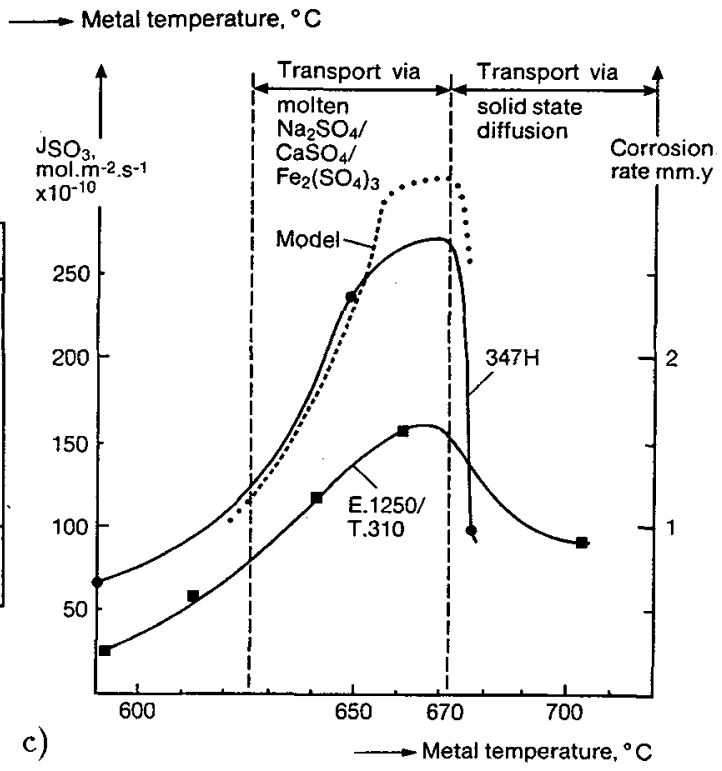

Fig. 3. - a) Corrosion rates of $347 \mathrm{H}, 310,446, \mathrm{Cr} 35 \mathrm{~A}$ and 671 at oil fired conditions of the $3 \mathrm{MW}$ th pilot plant at KEMA. b) Proposed transport reactions in the presence of a molten sulphate layer $\left(t_{\text {metal }}\right.$ : $\left.630-675^{\circ} \mathrm{C}\right)$. c) Calculated $\mathrm{SO}_{3}$ fluxes (dashed line) in the deposition layer as a function of the metal temperature. 


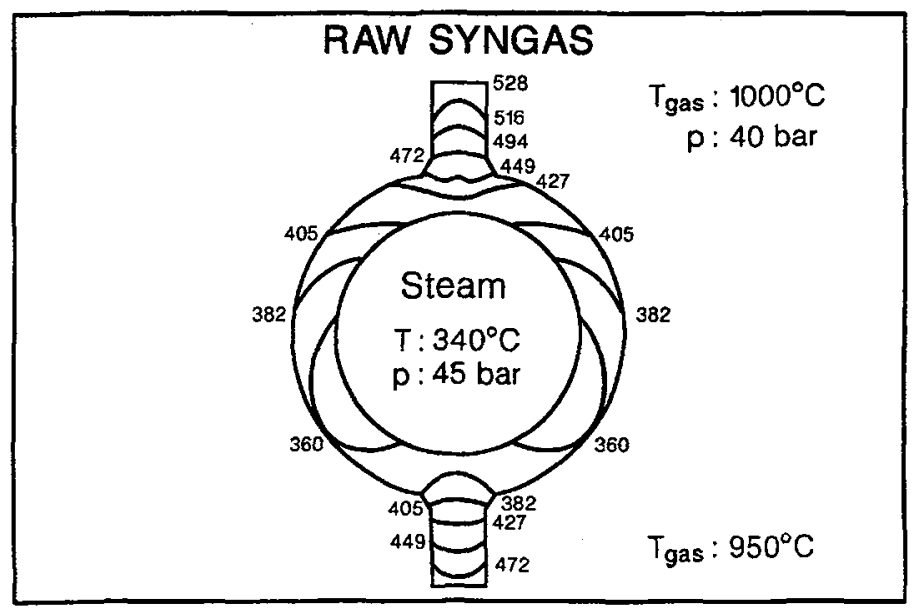

a)
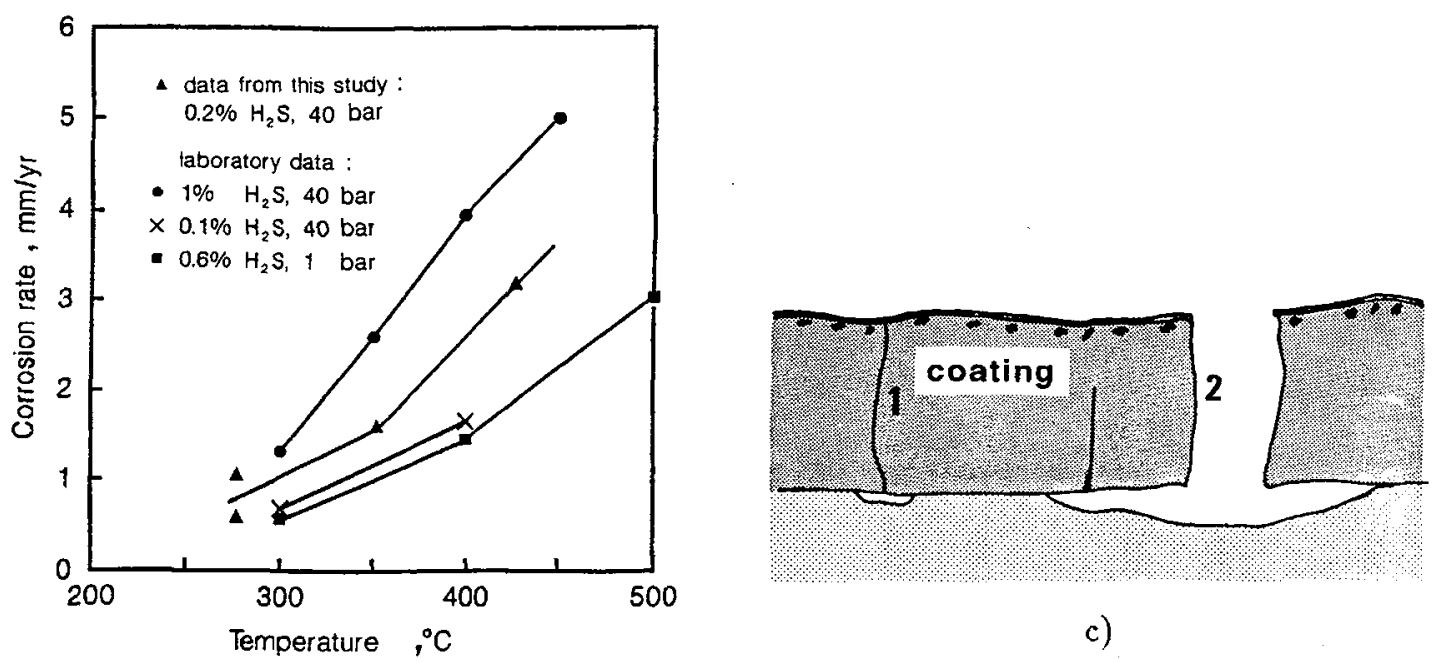

c)

b)

Fig. 4. - a) Calculated temperature distribution in one of the finned test probe. b) Corrosion rate of low alloy ferritic steels under gasification conditions; c) Schematic representation of the attack mechanism at Down Time Corrosion simulation of $\mathrm{Cr}$-, CrV-coatings in a gasifier. Stage 1 attack up till substrate. Stage 2 severe substrate attack.

the 250 MWe IGCC in Buggenum during 1993-1996 (participants Sep, Demkolec, KEMA). In the SAR project [3] eight steam cooled high temperature test loops are installed in the radiant cooler. The metal temperatures ranged, in order to simulate evaporator conditions, from $400-450{ }^{\circ} \mathrm{C}$ and to simulate super heater conditions from $512-570^{\circ} \mathrm{C}$. In figure 4 a a schematic view is given of the calculated temperature distribution in one of the finned test probes. Low alloyed boiler steels (with and without chromized coatings), austenitic stainless steel and high nickel alloys were exposed. The raw syngas composition contained $0.2 \% \mathrm{H}_{2} \mathrm{~S}$, $42 \% \mathrm{CO}$ and probably 400-800 ppm $\mathrm{HCl}$ and further $\mathrm{H}_{2}, \mathrm{CO}_{2}, \mathrm{H}_{2} \mathrm{O}, \mathrm{N}_{2}, \mathrm{CH}_{4}$. The total ex- 
posure time was about 3600 hours during which seven shut downs occurred. The test results demonstrated that the low alloyed boiler tubes suffer from unacceptable high corrosion rates caused by sulphidation possibly accelerated by chlorination. Vanadium modified chromium diffusion coatings on stabilized alloys are less subject to pitting and intergranular corrosion than previously tested chromium rich coatings. Coating failures can still be expected however after 10-20 000 hours of operation. Austenitic steels like AISI 310 tend to form thin protective scales at evaporator tube temperatures and are, in coextruded form on low alloy ferritic steel tubes, promising candidates for water wall tubes. An experimental alloy 26Cr, $41 \mathrm{Ni}, 3 \mathrm{~V}$ formed a thin continuous protective $\mathrm{Cr}_{2} \mathrm{O}_{3}$ scale with $\leq 1 \%$ sulphur in it during exposure at metal temperatures higher than $500^{\circ} \mathrm{C}$ and offer perspectives for use as super heater tube material.

Down time corrosion contributes to the overall corrosion rate of the materials in the gasifier and coolers: during down time periods the hygroscopic sodium- and iron chlorides in the deposits attract water, resulting in a very corrosive medium near which (electrochemical) corrosion reactions can occur. A series of $\mathrm{Cr}$ - and $\mathrm{CrV}$-coatings have been screened with a DTC test, developed by EPRI [4]. In this case a mixture of coalash/FeCl $/ 2 / \mathrm{NaCl}$ in the ratio $90 / 6 / 4$ was used. A classification of increasing resistance to DTC was obtained going from I to $\mathrm{V}$ :

I) Cr- and CrV-coatings on St.35 15Mo3 and Cr-coating on 10CrMo9.10;

II) Cr-coating on HR3C and CrV-coating on Inconel $800 \mathrm{H}$;

III) CrV-coatings on 10CrMo9.10;

IV/V) Cr- and CrV-diffusion coatings on Nb stabilized 10CrMo9.10 and 9Cr $1 \mathrm{Mo}$.

The attack varies from mild surface attack via pitting corrosion to intergranular attack. The last situation is schematically represented in figure $4 \mathrm{c}$.

\section{Conclusions.}

Concerning modern 150-200 MW gasturbines a growing need has been signaled for (blade) repair aspects available for the users of these machines.

About conventional coal fired boilers, equiped with low $\mathrm{NO}_{x}$ firing techniques, it was found that for repair purposes a CrV diffusion-coating on stabilized 10CrMo9.10 is promising. For super critical units it is concluded that under oil fired conditions the coextruded materials $1714 \mathrm{CuMo} / 35 \mathrm{CrA}$ (inside/outside) and $800 \mathrm{H} / 671$ will be suitable as superheater materials.

From tests under coal gasification conditions in practice it appeared that coextruded material with 310 outside is probably suitable for use as water wall tube and the material $26 \mathrm{Cr} 41 \mathrm{Ni3V}$ probably as superheater material.

\section{References}

[1] ZUILEN H.G., VAN LefERINK R.G.I., HuijBregtS W.M.M., Materialen 9 (1991) 21.

[2] BOLT N, Proceedings of the 10th Int. Congress on Metallic Corrosion Madras, vol. IV (1987) p. 3593.

[3] Liere J., VAN KiP J.B.M., DÜRRfeld R., HibBel J., BAKkeR W.T., Tagungsband Vorträge VGB-Konferenz Kohlevergasung, V26 (1991).

[4] EPRI Report AP-5966, Downtime Corrosion in Syngas Coolers of Entrained Slagging Gasifiers (1988). 